\title{
Changes in water binding during ripening of cheeses made from raw, pasteurized or high-pressure-treated goat milk
}

\author{
Martín BUFFA, Buenaventura GUAMIS, Jordi SALDO, Antonio J. TRUJILLO* \\ Planta de Tecnologia dels Aliments, CeRTA, XiT, Departament de Ciència Animal y dels Aliments, \\ Facultat de Veterinària, Universitat Autònoma de Barcelona, 08193 Bellaterra, Spain
}

(Received 29 November 2001; accepted 8 July 2002)

\begin{abstract}
The different types of water contained in the matrix of cheeses made from raw (RA), pasteurized $\left(\mathrm{PA} ; 72{ }^{\circ} \mathrm{C}, 15 \mathrm{~s}\right.$ ) or pressure-treated (PR; $\left.500 \mathrm{MPa}, 15 \mathrm{~min}, 20^{\circ} \mathrm{C}\right)$ goat milk were studied throughout ripening. Water content was qualitatively and quantitatively assessed by thermogravimetry. Thermogravimetric curves showed that water is lost in two successive steps $\left(\mathrm{W}_{1}\right.$ and $\mathrm{W}_{2}$ ), depending on the temperature required for water to leave the cheese network. Although water content in $\mathrm{W}_{1}$ and $\mathrm{W}_{2}$ of all cheeses followed similar trends, decreasing towards the end of ripening, large relative decreases were observed in $\mathrm{W}_{1}$. The highest decrease was observed in PA milk cheese, while PR milk cheese showed behavior similar to that made from RA milk. Differences in water binding could be attributable to changes in the cheese-matrix structure due to the technological treatment applied to milk, and/or physicochemical or biochemical differences $(\mathrm{NaCl}$, proteolysis, lipolysis, ...).
\end{abstract}

\section{Water binding / thermogravimetry / goat cheese / high-pressure treatment}

Résumé - Changements de l'eau liée des fromages faits à partir de lait de chèvre cru, pasteurisé ou traité par haute pression. Les différents types d'eau contenus dans la matrice des fromages faits à partir de lait de chèvre cru (RA), pasteurisé $\left(\mathrm{PA} ; 72^{\circ} \mathrm{C}, 15 \mathrm{~s}\right)$ ou traité par haute pression (PR ; $500 \mathrm{MPa}, 15 \mathrm{~min}, 20^{\circ} \mathrm{C}$ ) ont été étudiés durant la maturation. La teneur en eau a été qualitativement et quantitativement évaluée par thermogravimétrie. Les courbes thermogravimétriques ont montré que l'eau a été perdue en deux étapes consécutives $\left(\mathrm{W}_{1}\right.$ et $\left.\mathrm{W}_{2}\right)$, dépendant de la température que l'eau nécessite pour quitter le réseau du fromage. Bien que la teneur en eau dans $\mathrm{W}_{1}$ et $\mathrm{W}_{2}$ de tous les fromages ait suivi les mêmes tendances, en baissant vers la fin de la maturation, des baisses relatives élevées ont été observées dans $\mathrm{W}_{1}$. La décroissance la plus accentuée a été observée dans le fromage obtenu à partir du lait $\mathrm{PA}$, alors que le fromage obtenu à partir du lait $\mathrm{PR}$ a montré un comportement semblable à ceux faits à partir du lait RA. Les différences en eau liée peuvent être attribuées aux changements dans la structure de la matrice du fromage due au traitement technologique appliqué au lait, et/ou aux différences physico-chimiques ou biochimiques $(\mathrm{NaCl}$, protéolyse, lipolyse, ...).

Eau liée / thermogravimétrie / fromage de chèvre / traitement de haute pression

\footnotetext{
* Correspondence and reprints

Tel.: (34) 935813292; fax: (34) 935812006; e-mail: Toni.Trujillo@uab.es
} 


\section{INTRODUCTION}

The ripening of cheese is a complex process that involves chemical and biochemical reactions, water loss, salt diffusion, and changes in $\mathrm{pH}$ and in the microbial population. During ripening, water has a predominant role because it is the medium where these reactions take place. Water is also essential for the development of cheese microbiota, and through interaction with the cheese matrix, it contributes to the texture of cheese.

Although goat milk cheeses have been traditionally made from raw (RA) milk, aspects related essentially to microbial safety have increased the use of pasteurization treatments. However, most researchers have found that cheese made from pasteurized (PA) milk has higher moisture content than that made from RA milk, which in turn could cause differences in cheese firmness or in the cheese component degradation during ripening $[4,9]$.

The interest in non-thermal technologies, such as high-hydrostatic pressure, in milk has recently increased. Additionally to microbial destruction, high-pressure treatments induce numerous effects on the technological properties and milk components: fragmentation of casein micelles, aggregation of whey proteins and modifications of the mineral equilibrium [20], which cause changes in the rennet coagulation and cheese yield properties of pressure-treated (PR) milk [2, 18, 19]. The higher yields obtained from cheeses made from PR milk could be mainly attributed to the higher moisture content in these cheeses, a fact that alludes to the level of denatured whey proteins retained in these curds, and to the fragmentation of casein micelles produced by the pressure treatment [19].

Thermogravimetry (TG) is the branch of thermal analysis that examines the change in mass of a sample as a function of temperature in the scanning mode or a function of time in the isothermal mode [11], and it has been successfully applied in food analysis (studies of proteins, carbohydrates and fats) [7]. Measurement of the amount of moisture in foods is an obvious application for TG. Moisture can be present in the food matrix as bound or unbound water, and this degree of binding is reflected by the temperature at which mass is lost. When the matrix is heated, water is lost in successive stages, depending on the temperature required to break the bonds (hydrogen bonds, Van der Waals forces, London forces, etc.) formed between water and the cheese matrix [5].

The aim of this study was to quantify the different types of water contained in the matrix of cheeses made from RA, PA $\left(72{ }^{\circ} \mathrm{C}, 15 \mathrm{~s}\right)$ or PR $(500 \mathrm{MPa}, 15 \mathrm{~min}$, $20^{\circ} \mathrm{C}$ ) goat milk, and to compare their behaviors in relation to ripening time.

\section{MATERIALS AND METHODS}

\subsection{Cheese manufacture}

Goat cheese was manufactured from RA, PA $\left(72{ }^{\circ} \mathrm{C}, 15 \mathrm{~s}\right)$ and PR milk in two independent experiments, within an interval of one week. In each experiment, $50 \mathrm{~kg}$ of RA, $50 \mathrm{~kg}$ of PA and $50 \mathrm{~kg}$ of PR milk, from the same milk batch, were used for cheese-making.

High-pressure treated milk was obtained by using a semi-continuous hyperbar equipment (GEC Alsthom ACB, Nantes, France) by direct compression of the liquid with a piston. Batches of $4 \mathrm{~L}$ of milk were pressurized at $500 \mathrm{MPa}$ and 20 $\pm 1^{\circ} \mathrm{C}$ with a holding time of $15 \mathrm{~min}$. The pressure-chamber temperature was determined by means of a thermoregulation system that circulated heating cooling fluid (water) within the walls of the vessel. The increase in temperature caused by the adiabatic compression in the equipment was in the order of $2^{\circ} \mathrm{C}$ per $100 \mathrm{MPa}$, which was rapidly compensated for by the 
thermoregulation system. The PR milk was kept at $4{ }^{\circ} \mathrm{C}$ until cheese-making.

Milk was heated to $31{ }^{\circ} \mathrm{C}$ and then a starter culture (AM Larbus, Barcelona, Spain) containing Lactococcus lactis subsp. lactis and L. lactis subsp. cremoris, and $35 \%(\mathrm{w} / \mathrm{w}) \mathrm{CaCl}_{2}$ (food quality grade) were both added to cheese milk to a final concentration of $2 \%(\mathrm{w} / \mathrm{w})$ and $0.02 \%$ $(\mathrm{v} / \mathrm{w})$, respectively. Ten minutes later, $0.02 \%(\mathrm{v} / \mathrm{w})$ of calf rennet (Reniflor-15/E, Lamirsa, Barcelona, Spain), containing $780 \mathrm{mg} \cdot \mathrm{L}^{-1}$ chymosin was added. After $30 \mathrm{~min}$, the coagulum was cut, and the curds drained and moulded (13.6 $\times$ $13.2 \mathrm{~cm}$ ).

Due to the different technological treatments and in order to obtain cheeses with comparable moisture in non-fat material (M/NFM), which markedly influences the ripening of cheese [15], pressing time was established at $12 \mathrm{~h}(1 \mathrm{~h}$ at $1.3 \mathrm{kPa}$ and $11 \mathrm{~h}$ at $2.6 \mathrm{kPa}$ ). The pressing time used in this study was based on the experience gained from previous experiments.

After that, cheeses were salted by immersion in brine $(19 \% \mathrm{NaCl}$ solution) for $4 \mathrm{~h}$ at $14{ }^{\circ} \mathrm{C}$. Finally, cheeses, each one of approximately $1.31 \pm 0.03 \mathrm{~kg}$, were ripened in a room at $14{ }^{\circ} \mathrm{C}$ and $85 \%$ relative humidity for $60 \mathrm{~d}$.

\subsection{Compositional analysis}

Cheeses were analyzed for total solids and fat according to standard methods [12, 13]. Salt was determined by chloride analysis (Corning 926 Chloride Analyzer, Sherwood Scientific Ltd., Cambridge, UK). Liberation of free amino-acids was determined on the water-soluble cheese extract [14] by the Folkertsma and Fox cadmium-ninhidrin method [8]. The $\mathrm{pH}$ was measured in a cheese/distilled water (1:1) slurry.

For each of the two experiments, analyses of RA, PA and PR cheeses were per- formed in duplicate at 1, 30 and $60 \mathrm{~d}$ after cheese-making.

\subsection{Cheese weight-loss assessment}

A representative sample of the cheese batches (three cheeses from each batch of six) made from RA, PA and PR milk, in both experiments, was weighed weekly for nine weeks. Then, drying curves were drawn from the cheese-weight measurements.

\subsection{Thermal analysis}

Evaluation of the water contained in the matrix of cheeses was performed by thermogravimetry, using a TGA/SDTA851e thermobalance (Mettler-Toledo GMdH analytical, Schwerzenbach, Switzerland). Approximately $20 \mathrm{mg}$ of grated cheese was placed in the thermobalance sample pan and heated from 25 to $250^{\circ} \mathrm{C}$ at a scanning rate of $5^{\circ} \mathrm{C} \cdot \mathrm{min}^{-1}$, in a flow of nitrogen of $60-80 \mathrm{~mL} \cdot \mathrm{min}^{-1}$.

For each of the two experiments, analyses of RA, PA and PR milk cheeses were performed in triplicate at 1,30 and $60 \mathrm{~d}$ after cheese-making. The output signal from the thermobalance was evaluated using the Mettler-Toledo STARe software.

\subsection{Statistical analysis}

Data were processed by analysis of variance (ANOVA) using the general linear models procedure of SAS ${ }^{\circledR}$ System for WIN $^{\text {TM }}$ ( 8 version). The Student-NewmanKeuls test was used for comparison of sample data. Evaluations were based on a significance level of $P<0.05$.

\section{RESULTS AND DISCUSSION}

No differences $(P<0.05)$ in $\mathrm{M} / \mathrm{NFM}$ content were observed between cheeses on the first day of ripening (Tab. I). M/NFM of all cheeses decreased as they aged 
Table I. Composition of cheeses (mean and standard deviation) made from raw (RA), pasteurized (PA) and pressure-treated (PR) goat milk.

\begin{tabular}{cccccccc}
\hline & & \multicolumn{2}{c}{ Day 1} & \multicolumn{2}{c}{ Day 30} & \multicolumn{2}{c}{ Day 60} \\
\cline { 3 - 8 } $\mathrm{pH}$ & RA & $5.05^{\mathrm{a}}$ & 0.03 & 4.80 & 0.03 & $4.89^{\mathrm{a}}$ & 0.02 \\
& PA & $4.99^{\mathrm{b}}$ & 0.02 & 4.80 & 0.01 & $4.84^{\mathrm{b}}$ & 0.04 \\
& PR & $5.01^{\mathrm{b}}$ & 0.06 & 4.79 & 0.05 & $4.76^{\mathrm{c}}$ & 0.02 \\
$\mathrm{M} / \mathrm{NFM}$ & & & & & & & \\
$(\%)$ & RA & 2.45 & 0.05 & 1.33 & 0.05 & $1.01^{\mathrm{a}}$ & 0.02 \\
& PA & 2.47 & 0.08 & 1.29 & 0.05 & $0.92^{\mathrm{b}}$ & 0.01 \\
& PR & 2.43 & 0.05 & 1.36 & 0.04 & $0.98^{\mathrm{a}}$ & 0.02 \\
Salt/M & & & & & & & \\
$(\%)$ & RA & $1.76^{\mathrm{b}}$ & 0.52 & 5.00 & 0.56 & $6.92^{\mathrm{b}}$ & 0.41 \\
& PA & $2.25^{\mathrm{a}}$ & 0.53 & 5.30 & 0.68 & $7.51^{\mathrm{a}}$ & 0.40 \\
& PR & $1.77^{\mathrm{b}}$ & 0.41 & 5.00 & 0.50 & $7.03^{\mathrm{b}}$ & 0.54 \\
& & & & & & & \\
Free AA & RA & 0.45 & 0.10 & $2.16^{\mathrm{a}}$ & 0.08 & $4.56^{\mathrm{a}}$ & 0.69 \\
$\left(\mathrm{mg} \mathrm{Leu} \cdot \mathrm{g}^{-1}\right.$ cheese $)$ & PA & 0.45 & 0.07 & $1.09^{\mathrm{b}}$ & 0.37 & $3.07^{\mathrm{b}}$ & 0.98 \\
& PR & 0.41 & 0.04 & $1.87^{\mathrm{a}}$ & 0.14 & $4.03^{\mathrm{a}}$ & 0.57 \\
\hline
\end{tabular}

M/NFM: moisture in non-fat material; S/M: salt in moisture; AA: amino acids.

a,b, c Means within the same column without a common superscript are significantly different $(P<0.05)$.

(approximately 23-24\%) due to water surface migration-evaporation. However, after two months of ripening, PA milk cheese presented the lowest M/NFM values, suggesting that it had a greater water evaporation rate than RA or PR milk cheeses. On the other hand, salt inmoisture (S/M) content was higher $(P<0.05)$ in PA milk cheese than in that made from RA or PR milk.

Buffa et al. [3], using confocal laser scanning microscopy, observed that PA milk cheeses exhibited a less continuous matrix (open and porous) with more numerous and irregular spaces compared to RA or PR milk cheeses, which in turn each presented a more regular and closed protein network. However, as cheeses aged, the protein matrix became much more dense and compact, and differences between cheeses were less evident.

The microstructure described for PA milk cheese could explain its level of S/M, as well as the M/NFM content found at $60 \mathrm{~d}$. In relation to $\mathrm{S} / \mathrm{M}$ contents, when salting conditions are standardized (salting time, cheese geometry, brine temperature), the quantity of salt absorbed will depend mainly on the intrinsic properties of cheese. A relatively narrow pore width of the protein matrix exerts a frictional effect on the diffusing $\mathrm{NaCl}$ and $\mathrm{H}_{2} \mathrm{O}$ molecules, reducing their relative diffusion rates [10]. Therefore, the open microstructure of PA milk cheese could facilitate the $\mathrm{NaCl}$ diffusion into the cheese matrix, thus explaining the high S/M content observed in comparison to RA and PR milk cheeses. 


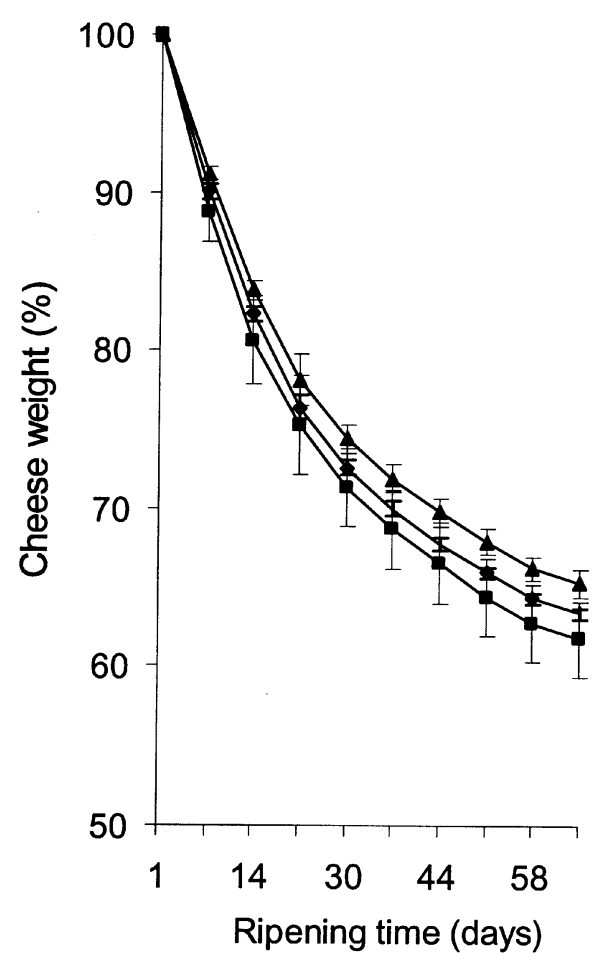

Figure 1. Drying curves $(n=6)$ of cheeses made from raw $(\bullet)$, pasteurized $(\boldsymbol{\square})$ and pressuretreated $(\mathbf{\Delta})$ goat milk during ripening.

Microstructure could also play an important role in the low M/NFM found in PA milk cheeses at the end of ripening. In the first stages of ripening, moisture might be located in the large interstitial spaces described for PA milk cheese. However, when proteolysis advances and the protein matrix becomes more homogeneous, large amounts of water may be released.

Drying curves of all cheeses also showed differences (Fig. 1). In agreement with M/NFM content data, PA milk cheese showed the fastest rate of weight-loss $\left(y=-10.925 \ln (x)+103.16 ; R^{2}=0.9415\right)$, while in the cheeses made from PR milk this process was significantly slower $(\mathrm{y}=$ $\left.-9.928 \ln (\mathrm{x})+03.32 ; \mathrm{R}^{2}=0.9237\right)$. RA milk cheeses, in turn, showed an intermediate behavior $(\mathrm{y}=-10.499 \ln (\mathrm{x})+103.27$;
$\left.R^{2}=0.9319\right)$. These results suggest that the water loss of cheeses during ripening is also controlled by the internal profiles of water in the cheeses, which in turn is related to the cheese-matrix microstructure, and not only by the external conditions of ripening.

Examination of curves from the TG, and their first derivatives, showed two partially overlapping weight-loss steps within the range $25-200{ }^{\circ} \mathrm{C}$ (Fig. 2). The presence of water over this range has been confirmed by De Angelis-Curtis et al. [5] by means of IR analysis. Each step is the result of the convolutions of a series of subprocesses corresponding to interactions between the water and different components of the matrix [5]. The first slight step corresponds to the water retained with less energy to the matrix $\left(\mathrm{W}_{1}\right)$, which is lost in the temperature range of 30 to $90-110^{\circ} \mathrm{C}$. The second step $\left(110-200^{\circ} \mathrm{C}\right)$ corresponds to the water more strongly linked to the cheese network $\left(\mathrm{W}_{2}\right)$, which requires more energy to break the bonds with the matrix. According to De Angelis-Curtis et al. [5], IR analysis of the gas produced indicates that other substances $\left(\mathrm{CO}_{2}\right.$, amines) also escape around $150{ }^{\circ} \mathrm{C}$. However, these losses of substances could be considered negligible compared to water desorption.

At the beginning of ripening, the $\mathrm{W}_{1}$ amount, which showed no differences $(P>0.05)$ between RA, PA and PR milk cheeses, represented nearly $60 \%$ of the total water of the system. The $\mathrm{W}_{1}$ content of all cheeses declined $(P<0.05)$ for the first $30 \mathrm{~d}$ of ripening, but thereafter this decrease was not significant (Fig. 3). The behavior of $\mathrm{W}_{1}$ is affected by a much larger series of parameters than $\mathrm{W}_{2}$, such as the transformation of $\mathrm{W}_{2}$ into $\mathrm{W}_{1}$, migration-evaporation processes, salt distribution, etc. [5]. During ripening of cheese, the liquid phase could be forced out easily by the diffusion gradient produced by water evaporation from the cheese body to the surface. However, the decrease in water of the system as cheese ages, brings down the diffusion gradient, 


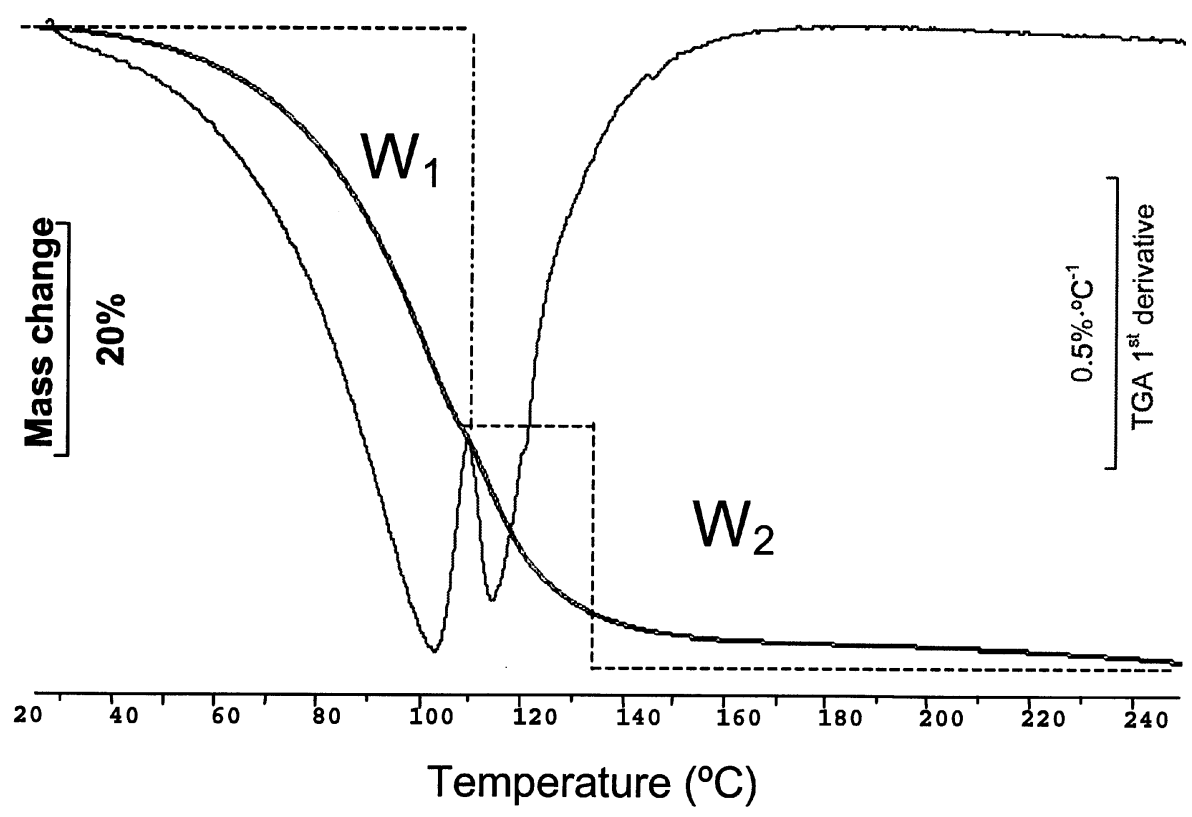

Figure 2. TG trace (bold line) and its corresponding first derivative (thin line) of a goat cheese. $\mathrm{W}_{1}$ and $\mathrm{W}_{2}$ indicate the two weight-loss steps.

consequently restricting the liquid phase movement. Additionally, the microstructure of a high moisture cheese (e.g. at the beginning of ripening) has high porosity, so that the liquid phase could be forced out easily by the diffusion gradient produced by the water evaporation [16]. As cheese water content decreases, cheese microstructure becomes more compact [17]. Thus, the cheese-matrix compaction may also restrict the liquid phase movement, decelerating in turn the migration-evaporation process.

The 30 and 60-d-old PA milk cheeses had lower $(P<0.05)$ amounts of $\mathrm{W}_{1}$ than RA or PR cheeses, which both showed similar values (Fig. 3). As we commented previously, S/M content was lower $(P<0.05)$ in cheeses made from RA or PR milk than in PA milk cheese (Tab. I). In this way, the lower salt concentration observed in both RA and PR milk cheeses leads to a reduction in the hydrophilic ions capable of binding water, with a conse- quent increase available "free water" [5]. Additionally, these results suggest that the rapid decrease in the $\mathrm{W}_{1}$ amount of PA milk cheeses could also be facilitated by their more open and porous microstructure [3].

As shown in Figure 3, no differences $(P>0.05)$ were found in the $\mathrm{W}_{2}$ amount of the 1-d-old RA, PA and PR cheeses, which decreased towards the end of ripening. The 30-d-old PA milk cheeses showed a higher $(P<0.05)$ percentage of $\mathrm{W}_{2}$ than $\mathrm{RA}$ or $\mathrm{PR}$ cheeses, whereas at the end of ripening no differences were found between cheeses.

The behavior of $\mathrm{W}_{1}$ and $\mathrm{W}_{2}$ in cheese is also affected by many other parameters, such as the effect of water migration-evaporation, salt diffusion, and proteolysis and lipolysis phenomena. Part of the system water is situated among the protein chains, becoming less free to move away. Thus, higher temperatures are required for the water to leave the cheese network. 

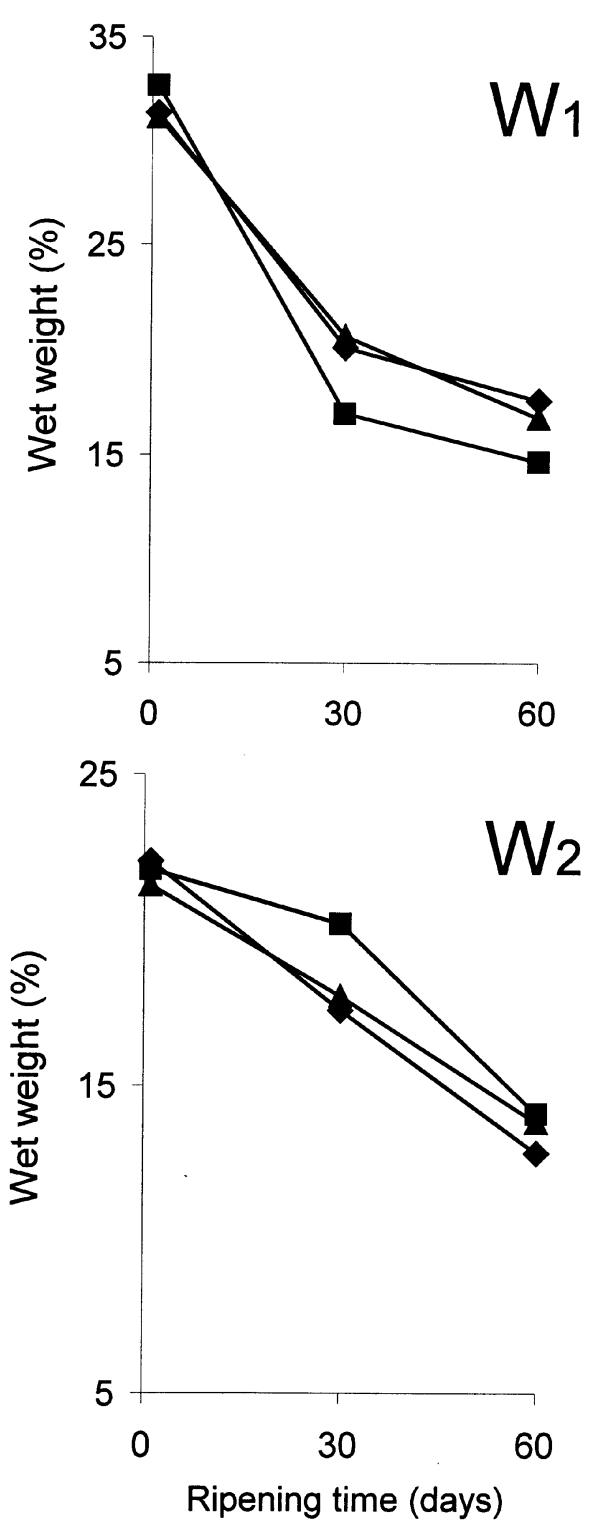

Figure 3. Evolution of $\mathrm{W}_{1}$ and $\mathrm{W}_{2}$ content of cheeses made from raw $(\bullet)$, pasteurized $(\boldsymbol{\square})$ and pressure-treated $(\boldsymbol{\Delta})$ goat milk during ripening. $\mathrm{W}_{1}$ is the water retained with less energy in the matrix, while $\mathrm{W}_{2}$ is the more strongly linked water.

De Angelis-Curtis et al. [5, 6] claimed that protein hydrolysis, and in a minor extent lipolysis, lead to release the water more strongly linked to the cheese matrix.

Cheese proteolysis, evaluated by the amount of free amino-acids, increased in all cheeses $(P<0.05)$ during ripening. However, proteolysis was more intense $(P<0.05)$ in both RA and PR milk cheeses than in PA milk cheese (Tab. I). Furthermore, it has been reported that cheeses made from PR milk showed a similar level of lipolysis to RA cheeses, whereas the level in PA milk cheese was lower, due to the thermal inactivation of native milk lipase [1]. Thus, the higher values of $\mathrm{W}_{2}$ observed in PA milk cheeses could account for their low proteolysis and lipolysis levels.

\section{CONCLUSIONS}

No differences were detected in the M/ NFM content of RA, PA and PR goat milk cheeses on the first day of ripening, however, PA cheeses showed a large rate of weight-loss during ripening.

Total water content, $\mathrm{W}_{1}$ and $\mathrm{W}_{2}$ of all cheeses decreased as cheese aged, indicating the significant effect of the ripening stage on cheese water binding. Large relative decreases were observed in the $\mathrm{W}_{1}$ content, which was the predominant type of water of 1-d-old cheeses. The highest decreases of $\mathrm{W}_{1}$ corresponded to PA milk cheese. During ripening, the $\mathrm{W}_{1}$ and $\mathrm{W}_{2}$ values of PR milk cheese showed a similar behavior to that of RA milk cheese, a fact that could be attributable to their similar cheese-matrix structure, and/or to the similarity of their main physicochemical or biochemical characteristics.

\section{ACKNOWLEDGEMENTS}

The authors acknowledge the EU for the financial support given to this investigation (FAIR: 96 1113; High-pressure treatment of liquid foods and derived products). Moreover, we wish to thank X. Felipe and J.M. Quevedo 
for assistance with cheese manufacture and S. Llorens for help with cheese analyses.

\section{REFERENCES}

[1] Buffa M., Guamis B., Pavia M., Trujillo A.J., Lipolysis in cheese made from raw, pasteurized or high-pressure-treated goats' milk, Int. Dairy J. 11 (2001) 175-179.

[2] Buffa M., Trujillo A.J., Guamis B., Rennet coagulation properties of raw, pasteurized or high-pressure treated goat milk, Milchwissenschaft 55 (2001) 243-246.

[3] Buffa M., Trujillo A.J., Pavia M., Guamis B., Changes in textural, microstructural, and colour characteristics during ripening of cheeses made from raw, pasteurized or highpressure-treated goat's milk, Int. Dairy J. 11 (2001) 927-934

[4] Creamer L.K., Olson N.F., Rheological evaluation of maturing Cheddar cheese, J. Food Sci. 47 (1982) 631-636.

[5] De Angelis Curtis S., Curini R., D’Ascenzo G., Sagone F., Fachin S., Bocca A., Grana Padano cheese: thermoanalytical techniques applied to the study of ripening, Food Chem. 66 (1999) 375-380.

[6] De Angelis Curtis S., Curini R., Delfini M., Brosio E., D’Ascenzo F., Bocca B., Amino acid profile in the ripening of Grana Padano cheese: a NMR study, Food Chem. 71 (2000) 495-502.

[7] Dyszel S.M., Applications of thermogravimetry in food technology, in: Harwalkar V.R., Ma C.Y. (Eds.), Thermal analysis of foods, Elsevier Science Publishers CO., Inc., New York, USA, 1990, pp. 333-357.

[8] Folkertsma B., Fox P.F., Use of the Cd-ninhydrin reagent to assess proteolysis in cheese during ripening, J. Dairy Res. 59 (1992) 217-224.

[9] Grappin R., Beuvier E., Possible implications of milk pasteurization on the manufac- ture and sensory quality of ripened cheese, Int. Dairy J. 7 (1997) 751-761.

[10] Guinee T.P., Fox P.F., Salt in cheese, in: Fox P.F. (Ed.), Cheese: Chemistry, Physics and Microbiology, Chapman and Hall, London, UK, 1993, pp. 389-438.

[11] Hatakeyama T., Quinn F.X., Thermogravimetry, in: Thermal analysis: fundamentals and applications to polymer science, John Wiley \& Sons Ltd., Chichester, UK, 1994, pp. 38-64.

[12] IDF, Cheese and processed cheese. Determination of the total solids content. Standard 4A. Int. Dairy Fed. Brussels, Belgium, 1982.

[13] ISO, Cheese- Determination of fat contentvan Gulic method. Standard 3433, Int. Organization for Standarization, Leusden, Netherlands, 1975.

[14] Kuchroo N.C., Fox P.F., Soluble nitrogen in cheese: comparison of extraction procedures, Milchwissenschaft 37 (1982) 331-334.

[15] Lawrence R.C., Creamer L.K., Gilles J., Texture development during cheese ripening, J. Dairy Sci. 70 (1987) 1748-1760.

[16] Pierre A., Michel F., Le Graët Y., Berrier J., Soft goat cheeses at different ripening stages: cheese structure, composition and nonsolvent water, Lait 79 (1999) 489-501.

[17] Stanley D.W., Emmons D.B., Cheddar cheese made with bovine pepsin. 2. Texture, microstructure and composition relationships, J. Inst. Can. Sci. Tech. Alim. 10 (1977) 78-84.

[18] Trujillo A.J., Royo C., Ferragut V., Guamis B., Ripening profiles of goat cheese produced from milk treated with high pressure, $\mathrm{J}$. Food Sci. 64 (1999) 833-837.

[19] Trujillo A.J., Royo C., Guamis B., Ferragut $\mathrm{V}$., Influence of pressurization on goat milk and cheese composition and yield, Milchwissenschaft 54 (1999) 197-199.

[20] Trujillo A.J., Capellas M., Buffa M., Royo C., Gervilla R., Felipe X., Sendra E., Saldo J., Ferragut V., Guamis B., Application of high pressure treatment for cheese production, Food Res. Int. 33 (2000) 311-316. 